\title{
Digitalisation and Labour: A Rejoinder to Christian Fuchs
}

\author{
César Bolaño
}

\author{
Federal University of Sergipe, Aracaju-Sergipe, Brasil, bolano.ufs@gmail.com
}

\begin{abstract}
I have published a paper about social network sites in the journal Television \& New Media, criticising some ideas of Christian Fuchs, who considers the mere act of surfing on commercial websites using targeted advertising, such as Facebook, a form of labour. His rejoinder deserves some responses from me. We share the same concern about the need to analyse the Internet from a Marxist perspective-revealing its dominative features and its functions as an instrument of exploitation, while considering the counter-hegemonic possibilities allowed by the system structure or, as Fuchs puts it, regarding the fact that "alternatives to Facebook and the capitalist Internet are needed". Although, Fuchs in his response concerns mainly one major idea, he makes the same mistake as Dallas Smythe regarding the labour theory of value. In his rejoinder he refers to some old polemic issues known in the Marxist debate that have nothing to do with the problem itself.
\end{abstract}

Keywords: Audience; Political Economy; Labour; Commodity

Acknowledgement: The two articles, on which this contribution is based, are:

Bolaño, César R. S. and Eloy S. Vieira. 2015. The Political Economy of the Internet: Social Networking Sites and a Reply to Fuchs. Television \& New Media 16 (1): 52-61.

Fuchs, Christian. 2015. Against Divisiveness: Digital Workers of the World Unite! A Rejoinder to César Bolaño and Eloy Vieira. Television \& New Media 16 (1): 62-71.

In the following few pages, I intend to briefly clarify some points that might be developed in the future, not necessarily by me.

1. In the abstract of his rejoinder, Fuchs points out that Smythe's contribution stands in the context of other approaches that emerged during the same period "when both feminist and anti-imperialist Marxists challenged the orthodox idea that only white factory workers are exploited". Even recognizing the significance of his founder work, I am not a disciple of Smythe and I am not aware of his position towards feminism and imperialism. I do have my own definition of the "audience commodity" that is certainly more orthodox than the one by Fuchs and differs from Fuchs' interpretation of the concept (Bolaño 2000). I do not agree that, "the crucial question is how to conceptualize productive labor". What really matters in this case is the concept of labour itself and the complex relations between production, distribution, and consumption that Marx enlightens in "A Contribution to the Critique of Political Economy".

2. I do not adopt a perspective that confirms the following statement: "you can only be exploited and therefore what Marx calls a productive worker if you earn a wage". Slaves are exploited and do not earn any kind of wage. So are servants. Many kinds of primitive capital accumulation survive inside capitalism's core, which implies that the wage form is not strictly necessary. There are interesting examples like these in the digital economy such as independent production models that, in the end, are appropriated by capital. The relation between the mercantile and the non-mercantile in the Internet economy is an example of the outsourcing of production costs. Even inside the old culture Industry, the wage form is commonly replaced or supplemented for other ways of labour incorporation. The attempt to renew the copyright system is just a part of this logic. 
3. The entire discussion is interesting and is part of a major research field in which both of us are immersed: in the Political Economy of Communication. Marx describes the features of capitalist exploitation's core by unveiling the origin of surplus-value in the capitalist model of production and not in the context of mercantile capitalism that existed before the Industrial Revolution. The most important Marxian concept to comprehend this phenomenon is the capitalist subsumption of labour. The wage form is inherent to general subsumption (what Marx terms formal subsumption), but this is a complex issue because the wage form itself does not imply real subsumption. This is another complex topic that can be added to the one mentioned in $\S 2$.

4. For Marx, the definition of productive labour is linked to this issue. So indeed for him not "only wage-workers in factories are productive workers". Capitalist exploitation can also exist in agriculture or in any other kind of productive activity, including education, music, or medicine, as Marx states in an unpublished chapter of Capital Volume 1, the Results of the Immediate Process of Production. In Marx's definition, there are no observations about ethics or morals, nor any references to gender or to ethnicity. Productive labour is not the same as useful labour, good labour, necessary labour, or labour essential to society. Productive labour is the one that directly produces value and surplus value. It is useful, good, or necessary to capital. It does not matter if it is conducted by a white man or by a black woman.

5. Thus, the idea of "conceptualizing somebody as unproductive is not only an analytical term, but it is also a slur and quite emotive" is absurd. For example, a professor working in a public university, like I do, is fundamental to social reproduction and his work is unproductive even though it is part of knowledge production, appropriated directly by the capitalist corporation, which transforms it into technology. Domestic labour is also unproductive, but society does not survive (yet) without it because it is essential to the reproduction of the working class, being useful essentially to reduce the value of the workforce, maintaining the standard capitalist exploitation that has its roots in pre-capitalist, patriarchal, and cultural practices of domination.

6. Fuchs also writes about the use of the productive labour concept in the Soviet Union. But, as I aforementioned, Marx's definition is part of his critique of political economy. The use of the concept to establish the distribution norms in a planned economy can be done, as was the case in the Soviet Union, but it is completely arbitrary. It is so because in a rationally organised system that intends to eliminate any form of exploitation and social domination there are no "technical" reasons to consider the domestic labour that serves the workforce's reproduction as unproductive. The adoption to this capitalist criterion serves, indeed, the maintenance of those same patriarchal forms of domination. Something similar occurs when Taylorist concepts are imported in order to elevate labour productivity, regardless of the crucial separation between manual and intellectual work, as explained by Sohn-Rethel in his criticism of the Soviet model.

7. An analysis of gender and ethnicity, after all, is still rather a blank in orthodox Marxism. And this has been the case for a long time in the core of the old workers movement. The "new social movements"-women's struggles, decolonisation, the struggles of black people, students, amongst many others-clearly exposed this issue in the 1960s. Since then, the separation between these two conceptions of social transformation, that affects the utopian horizons of all social movements, has not been solved and this is also evident nowadays.

8. The criticisms that can be made of Marxism and Marx himself on this issue are complex. The work of Anibal Quijano, for example, is of fundamental importance for comprehending the ethnicity issue, and is deeply radical in its criticism of historical materialism. Regarding feminism, I only want to mention the excellent work of Anne McClintock (1995), who articulates gender relations, ethnicity, and class issues in the analysis of English imperialism. The recognition of the relevance and the need to do a post-colonial criticism of standard left think- 
ing should not lead Marxist intellectuals to downplay central elements of Marx's labour theory.

9. Fuchs hesitates about how to interpret my conception of work on social network sites. It seems it is not entirely clear if I refer to "only Facebook's paid employees or also the paid employees working for its advertising clients in production and/or sales and advertising departments". My concept is not different from Marx's. We should not consider the financial or commercial employees' labour as productive. When I analysed the advertisement sector in my work, I used Marx's perspective on the transportation and telecommunication sector that for him constitutes exceptions in the realm of "circulation costs" (Bolano 2000). At that occasion, I also provided in one of my books a criticism of Baran and Sweezy, whom Fuchs also criticises in his text. Fuchs's position is not distinct from that of Dallas Smythe. I, in contrast, gave a completely different solution.

10. Fuchs includes my work among a group of recent English-writing authors that I am not aware of, comparing them to a criticism that Lebowitz made of Smythe in 1986 that I am also not aware of. What makes all of these perspectives similar, according to Fuchs, is that they consider "digital labour" on advertising-funded social media platforms as not exploited. The definition of labour as productive or unproductive does not depend on the product's nature itself (as digital or analogue). I believe that many elements that lead to a more complex discussion were already shown previously, but the main issue here is that this has nothing to do with the central problem that I originally pointed out in the work of Smythe and Fuchs: consumption is not labour. There are many forms of labour on the Internet and at the digital workplace that need to be analysed. What I meant to say is that we cannot count the act of surfing or just posting personal information on commercial social networking sites among these forms of online labour because it is clearly a form of unproductive consumption, according to Marx's expression.

11. Indeed, these consumers are active and provide information that will be used by the social media companies in the valorisation process. I already explained this circumstance in my original paper. However, there is more: consumers' online activities are part of learning and an adaptation to the digital environment that in the private sphere reproduces the forms of interaction, use and appropriation of techniques and technologies used in the labour environment. If these environments (consumption and labour) appear to be mixed, then a good theory must be able to unveil this fact. The deconstruction of appearances at the intellectual level is precisely what Marx defined as ideology critique. This unveiling is indeed a task of Political Economy Criticism. Marx's criticism refers to classical bourgeois political economy, vulgar political economy, Proudhon's misguided thinking, etc.

12. Fuchs makes an analytical mistake when he states that, "capital accumulation requires not only wage-labor but also exploitation of various forms of colonies that are sources of cheap, underpaid, unpaid, and precarious labor". Tugan-Baranovisky showed that it is not necessary, but true that, historically, the introduction of the wage form in West Europe and the constitution of the capitalist production system, happened concomitantly with the disappearance of the feudal system in East Europe and the slavery system in America. Getting back to Fuchs's discussion: "Smythe added to this discourse the idea that audience commodification is yet another form of outsourcing labor and value-production to an unremunerated sphere from which capital derives profits". What relation could exist between the exploitation of labour in the colonies (which was passing through a decolonization process after World War II) and the TV audience in the USA? Fuchs's statement, many decades after decolonisation and regardless of all criticism of Smythe made by the English Political Economy of Communication-stream of Smythe, is incomprehensible.

13. Fuchs' statement does not make much sense and is kind of simplistic: "Marx's concept of productive labor is a political concept aimed at identifying who holds the power and capacity 
to conduct a revolution against capitalism". Let's be cautious. Marx's work published in Capital is a wide philosophical project that intends to be a materialist dialectic. He grounded this approach already in his 1844 Economic and Philosophical Manuscripts. Marx's work is all about the inversion of the Hegelian logic, seeking in reality itself the contradictions that determine its development. Critical Political Economy shows the revolutionaries' features by indicating the working class's position in the inner structure of production. The first Marxist orthodoxy, from Engels and Kautsky, according to that perspective, ruined any revolutionary project in countries such as Germany at the time of Marx or Russia at the time of Lenin. The Bolsheviks's partial rupture of this perspective on the revolutionary process divided the Marxist left into (superficially speaking) two sides.

14. A debate like this demands a large amount of theoretical engagement in order to cover all the issues we are dealing with. The usefulness of an exercise like this after the fall of Soviet Union is doubtful. It could be even worse, of course, if we spent our time to figure out if Marx was sexist or racist. No, he was not. But, what really matters here-and this has been my main concern since I first made my hypothesis of intellectual labour subsumption (Bolano 1995) - is to get back to Marxian thought in order to comprehend the features of the new working class that emerged after the structural crisis in the 1970s.

15. Many authors have dedicated work to the analysis of how the working class has changed. The field of the Political Economy of Communication should take this task as its major research programme today. Such a task could give some academic dimension to the appeal for unification ("Digital workers of the world unite!") that Fuchs made in his rejoinder to my paper. It is in contrast worthless to reduce the concept of labour or to replace the Marxist concept of the working class by the concept of crowd labour.

Fuchs's rejoinder also faces problems when dealing with fundamental concepts such as socially necessary labour, profit, the rate of surplus-value, and the relation of "macro/micro". I do not intend to go into these details. Nevertheless, I intended to make a constructive criticism: The PEC field should make intellectual workers recognise themselves as part of a new working class of the $21^{\text {st }}$ century. This new working class is rising and it is profoundly intellectualised because of the contemporary capitalist system, which demands so in order to maintain its continuous process of valorisation. This is the only kind of union that may take us out from this "control society" that capitalism has become. Due to the development of the productive forces, it is possible to think again about the possibility of overcoming the separation between manual and intellectual labour.

\section{References}

Bolaño, César R. S. 1995. Economia Política, Globalización y Comunicación. In: Revista Nueva Sociedad, 140, Caracas.

Bolaño, César R. S. 2000. Indústria Cultural, Informação e Capitalismo. São Paulo: HUCITEC.

Bolaño, César R. S. and A. Cabral. 2014. O Brasil e o Movimento Social Global: Uma Análise dos Eventos de Junho de 2013 em Perspectiva Histórica. Liinc em Revista 10 (1). revista.ibict.br/liin.

McClintock, Anne. 1995. Couro imperial. Raça, Gênero e Sexualidade No Embate Colonial. Camipnas: Ed. UNICAMP, 2010.

\section{About the Author}

César Bolaño

César Bolaño holds a PhD in Economic Science from the University of Campinas (Unicamp). He is Professor at Universidade Federal de Sergipe (UFS), Brazil. He is the author of Mercado Brasileiro de Televisão (São Paulo: EDUC); Televisão Brasileira na era digital (São Paulo: PAULUS); Political Economy, communication and knowledge (ORG.; Buenos Aires: La Crujía); Qual a lógica das políticas em comunicação no Brasil? (São Paulo: PAULUS). His research is concerned with a marxist perspec- 
tive of Communication and Culture and with the field of the Political Economy of Culture and Communication. 